\title{
SISTEM KETATANEGARAAN INDONESIA PADA MASA DEMOKRASI LIBERAL TAHUN 1950- 1959
}

Johan Setiawan

Program Studi Pendidikan Sejarah, Program Pascasarjana Universitas Negeri Yogyakarta johansetiawan767@gmail.com

\section{Wahyu Ida Permatasari}

Program Studi Pendidikan Sejarah, Program Pascasarjana Universitas Negeri Yogyakarta wahyuidapermatasari@gmail.com

\section{Dyah Kumalasari}

Program Studi Pendidikan Sejarah, Program Pascasarjana Universitas Negeri Yogyakarta dyahkumala@gmail.com

\begin{abstract}
Abstrak
Penelitian ini bertujuan untuk mengetahui bagaimana landasan dasar sistem ketatanegaraan Indonesia, kelengkapan alat-alat negara dan kabinet-kabinet yang memerintah pada masa demokrasi liberal tahun 1950-1959. Penelitian ini menggunakan metode sejarah dengan langkah sebagai berikut: (1) heuristik, (2) kritik sumber, (3) interpretasi, (4) historiografi. Hasil penelitian yang diperoleh yaitu: (1) Landasan dasar yang digunakan dalam demokrasi liberal yaitu UUDS 1950,(2) Alat-alat kelengkapan negara menurut UUDS 1950 yaitu Presiden dan Wakil Presiden, menteri-menteri, Dewan Perwakilan Rakyat, Mahkamah Agung dan Dewan Pengawas Keuangan, (3) Kabinet yang memerintah masa demokrasi liberal di Indonesia 1950-1959 yaitu Kabinet Natsir, Kabinet Sukiman, Kabinet Wilopo, Kabinet Ali Satromidjojo I, Kabinet Burharuddin Harahap, Kabinet Ali Satromidjojo II dan Kabinet Djuanda
\end{abstract}

Kata kunci: sistem ketatanegaraan indonesia, demokrasi liberal, 1950-1959.

\begin{abstract}
This study aims to find out how the basic foundation of the Indonesian state administration system, the completeness of state tools and the cabinets that ruled during the liberal democracy of 1950-1959. This study uses historical method with the following steps: (1) heuristics, (2) source critic, (3) interpretation, (4) historiography. The results of the research are: (1) The basic foundation used in liberal democracy is UUDS 1950, (2) State apparatus according to UUDS 1950 namely President and Vice President, Ministers, House of Representatives, Supreme Court and Supervisory Board, (3) Cabinet governing the period of liberal democracy in Indonesian 1950-1959 is Natsir Cabinet, Sukiman Cabinet, Wilopo Cabinet, Ali Satromidjojo I Cabinet, Burharuddin Harahap Cabinet, Ali Satromidjojo II Cabinet and Djuanda Cabinet.
\end{abstract}

Keywords: indonesian state administration system, liberal democracy, 1950-1959.

\section{PENDAHULUAN}

Pelaksanaan Demokrasi Liberal yang dijalankan oleh Indonesia sesuai dengan konstitusi yang berlaku pada saat itu, yakni Undang-Undang Dasar Sementara 1950. Kondisi ini bahkan sudah dirintis sejak di keluarkannya maklumat pemerintah pada tanggal 16 Oktober
1945 dan maklumat tanggal 3 November 1945, tetapi kemudian terbukti bahwa Demokrasi Liberal yang meniru sistem Eropa kurang sesuai di terapkan di Indonesia.

$$
\text { Demokrasi Liberal yang }
$$

berlangsung pada tahun 1950 hingga Juli 1959 merupakan waktu di mana partai- 
partai politik berkiprah. Saat itu Partai PNI dan Partai Masyumi merupakan dua partai politik yang terkuat dalam memimpin kabinet. Karena sering bergantinya kabinet pada masa demokrasi liberal berimplikasi terhadap ketidakstabilan pada politik, sosial, ekonomi, dan keamanan.

Sistem Politik pada masa Demokrasi Liberal di Indonesia pada tahun 1950-1959 mendorong untuk lahirnya partai-partai politik. Hal ini dikarenakan menganut sistem multipartai atau lebih dari satu partai yang mencoba untuk silih berganti dalam memperoleh kekuasaan eksekutif maupun legislatif. Di mana lembaga legislatif seperti DPR dan Parlemen memiliki kekuasaan yang lebih besar dibandingkan dengan lembaga eksekutif yang terdiri dari Presiden dan Wakil Presiden maupun menteri-menteri.

Sistem pemerintahan yang dikehendaki pada masa demokrasi liberal menggunakan Undang-Undang Dasar Sementara (UUDS) tahun 1950 adalah sistem parlementer, dimana dalam hal ini kabinet tidak bertanggung jawab kepada Presiden seperti yang ditentukan oleh Undang-Undang Dasar (UUD) 1945. Tetapi dalam UUDS 1950 bertanggung jawab kepada Dewan Perwakilan Rakyat atau dalam istilah yang hidup ketika itu disebut sebagai parlemen (Zulfikar Gazali, Anhar Gonggong dan JR Chaniago,1989: 11-12).
Di Indonesia, sistem politik liberal berjalan kurang lebih 9 tahun dari 17 Agustus 1950 sampai dengan 5 Juli 1959. Akan tetapi pada waktu yang singkat itu Indonesia telah 7 kali pergantian kabinet yang memerintah antara lain: Kabinet Natsir (6 September 1950-21 Maret 1951), Kabinet Sukiman (27 April 1951-3 April 1952), Kabinet Wilopo (3 April 1952-3 Juni 1953), Kabinet Ali Satromidjojo I (31 Juli 1953-12 Agustus 1955), Kabinet Burharuddin Harahap (12 Agustus 1955-3 Maret 1956), Kabinet Ali Satromidjojo II (20 Maret 1956-4 Maret 1957), dan terakhir Kabinet Djuanda ( 9 April 1957-5 Juli 1959).

Berdasarkan latar belakang diatas, maka rumusan masalah dalam penelitian ini adalah bagaimanakah sistem ketatanegaraan Indonesia pada masa demokrasi liberal tahun 19501959?. Tujuan penelitian ini adalah untuk mengetahui bagaimana landasan dasar sistem ketatanegaraan Indonesia, kelengkapan alat-alat negara dan kabinet-kabinet yang memerintah pada masa demokrasi liberal tahun 1950-1959.

\section{METODE}

Metode yang digunakan dalam penelitian ini adalah metode penelitian historis, karena penelitian ini mengambil objek dari peristiwa-peristiwa yang terjadi pada masa lampau. Menurut Nugroho Notosusanto (1984: 11) langkah-langkah dalam penelitian historis, yaitu: (1) Heuristik adalah proses mencari untuk 
menemukan sumber-sumber sejarah. Peneliti mencoba mencari serta mengumpulkan sumber-sumber sejarah yang diperlukan. Kegiatan heuristik juga difokuskan untuk mencari buku-buku literatur yang sudah ditulis oleh sejarawan, (2) Kritik adalah menyelidiki apakah jejak sejarah itu asli atau palsu. Dalam penelitian ini peneliti mencoba untuk mencari tahu dan membuktikan kealsian dari sumber-sumber yang peneliti dapat, setelah itu peneliti membandingkan dan memilih dari beberapa buku dan sumber yang peneliti yakini bahwa berita dan sumbernya dapat dijadikan pedoman dalam penulisan penelitian ini, (3) Interpretasi setelah mendapatkan fakta-fakta yang diperlukan maka kita harus merangkaikan fakta-fakta itu menjadi keseluruhan yang masuk akal, Historiografi adalah suatu kegiatan penulisan dalam bentuk laporan hasil penelitian yang menggunakan keterampilan dalam mengutip dari buku dengan sumber-sumber yang ada. Penyusunan dan penulisan ini menggunakan pemikiran yang kritis dan analisis sehingga menjadi sebuah kisah sejarah yang sistematis.

\section{HASIL DAN PEMBAHASAN}

Landasan Dasar Sistem Parlementer (Demokrasi Liberal) di Indonesia

Pembentukan negara kesatuan setelah masa Republik Indonesia Serikat (RIS) menandakan babak baru periode pemerintahan bangsa Indonesia. Kesepakatan antara RIS dan RI untuk membentuk negara kesatuan tercapai pada tanggal 17 Mei 1950, dengan ditandatanganinya Piagam Persetujuan antara RIS dan RI. Isi piagam tersebut menyatakan bahwa kedua belah pihak antara RIS dan RI dalam waktu yang sesingkat-singkatnya dan secara bersama-sama akan melaksanakan pembentukan negara kesatuan (Soepomo, 1950: 133-139).

Periode ini berlangsung mulai 17 Agustus 1950 sampai 5 Juli 1959 yang disebut dengan sistem Parlementer. Perancang landasan dasar demokrasi liberal atau sistem parlementer di Indonesia dirancang oleh Panitia Gabungan RIS dan RI atau disebut dengan Panitia Persiapan Undang-Undang Dasar Negara Kesatuan yang diketuai oleh Menteri Kehakiman RIS yaitu Prof. Supomo dan wakil ketua yaitu Perdana Menteri RI, Dr. Abdul Halim (Anhar Gonggong dan Musa Asy'ari, 2005: 57).

Pekerjaan rancangan UUD Negara Kesatuan baru selesai tepatnya pada tanggal 20 Juli 1950. Undang-Undang tersebut kemudian dibahas oleh DPR masing-masing, dan diterima oleh senat dan parlemen RIS maupun KNIP. Barulah pada tanggal 15 Agustus 1950 Presiden Soekarno menandatangani rancangan UUD tersebut yang kemudian dikenal dengan Undang-Undang Dasar Sementara 
Republik Indonesia tahun 1950 (Marwati Djoened Poesponegoro dan Nugroho Notosusanto, 2008: 307), kemudian secara resmi Negara Kesatuan dibentuk pada tanggal 17 Agustus 1950.

Landasan demokrasi liberal ini adalah Undang-Undang Dasar Sementara (UUDS) 1950. Undang-Undang Dasar Sementara 1950 terdiri dari dari Mukadimah dan Batang Tubuh, yang meliputi 6 bab dan 146 pasal (Zulkarnain, 2012: 10). Enam bab tersebut mengatur tentang Negara Kesatuan Republik Indonesia, alat-alat kelengkapan negara, tugas alat-alat perlengkapan negara, pemerintah daerah, daerah-daerah swapraja, konstituante dan perubahan, ketentuan-ketentuan peralihan dan ketentuan penutup.

Sistem pemerintahan yang dianut dan diterapkan pada masa berlakunya UUDS 1950 ini adalah sistem pemerintahan parlementer. Kabinet di dalam sistem parlementer tidak bertanggung jawab kepada Presiden seperti yang ditentukan oleh UndangUndang Dasar 1945, tetapi dalam UUDS 1950 kepada Dewan Perwakilan Rakyat. Meskipun begitu, kekuasaan Presiden dan Wakil Presiden tetap diakui. Terdapat pada pasal 83 ayat (1) UUDS 1950, Presiden dan Wakil Presiden tidak dapat diganggu-gugat (Zulkarnain, 2012: 103).

Artinya Presiden dan Wakil Presiden di dalam sistem parlementer UUDS 1950, masih diakui meskipun tugas menjalankan pemerintahan dipegang oleh perdana menteri dan menterimenteri terpilih. Sebenarnya UUDS 1950 hanyalah bersifat sementara, sifat kesementaraan ini jelas terlihat dan tertulis pada pasal 134 yang menyatakan konstituante yaitu Lembaga Pembuat UUD yang bersama-sama dengan pemerintah selekas-lekasnya menetapkan UUD Republik Indonesia yang akan menggantikan UUDS ini (Zulkarnain, 2012: 111).

\section{Kelengkapan Negara Pada Masa Sistem Parlementer}

Alat-alat kelengkapan negara menurut UUDS 1950, ketentuan Umum, pasal 44, ialah; Presiden dan Wakil-Presiden, menteri-menteri, Dewan Perwakilan Rakyat, Mahkamah Agung dan Dewan Pengawas Keuangan. Jika melihat pasal 45 ayat (1) tertuang bahwa Presiden hanya berstatus sebagai Kepala Negara. Artinya kekuasaan Presiden ialah hanya sebagai kepala negara tanpa menjalankan roda pemerintahan secara langsung.

Sistem parlementer pada masa demokrasi liberal ini Presiden dan Wakil Presiden hanyalah sebagai simbol yang tidak memiliki fungsi pemerintahan sehari-hari. Namun, Presiden tetap dapat menyetujui perdana menteri baru atau tetap dapat mengeluarkan dekrit. Menurut UUDS 1950, kekuasaan legislatif 
di pegang oleh Presiden, kabinet dan DPR (Zulkarnain, 2012: 103).

Perdana Menteri yang menjabat sebagai kepala pemerintahan dan menjalankan roda pemerintahan seharihari serta memimpin kabinet disetujui oleh Presiden. Kabinet keseluruhan maupun secara perorangan bertanggungjawab kepada DPR yang mempunyai hak untuk menjatuhkan kabinet secara seluruhnya ataupun memberhentikan menteri-menteri secara individual. Artinya yang mengangkat Perdana Menteri dan kabinet adalah DPR atas persetujuan Presiden.

Sistem politik pemerintahan pada masa ini pula mendorong untuk lahirnya partai-partai politik, karena sistem kepartaian menganut sistem multipartai. Akibat yang didapat dari pelaksanaan sistem politik demokrasi liberal ini yang mengikuti sistem pemerintahan gaya Eropa, maka partai-partailah yang menjalankan pemerintahan melalui kekuasaannya di parlemen. Untuk wilayah kekuasaan negara Kesatuan Indonesia pada masa demokrasi parlementer dibagi menjadi 10 daerah provinsi yang otonom.

\section{Kabinet-kabinet Pada Masa Sistem Parlementer}

Antara tahun 1950-1959 sudah terjadi 7 (tujuh) kali pergantian kabinet. Pergantian kabinet ini hampir terjadi setiap tahun hingga berakhirnya Undangundang Dasar Sementara (UUDS) 1959.
(Zulkarnain, 2012: 11). Pergantian kabinet yang terjadi dalam waktu singkat ini menandakan lemahnya kekuatan kabinet sehingga dapat dikudeta atau dijatuhkan oleh partai atau orang lain.

Berikut kabinet-kabinet pada masa Sistem Parlementer:

\section{Kabinet Natsir}

Kabinet pertama yang menjalankan pemerintahan ialah Kabinet Natsir, yang berlangsung sejak 6 September 1950 sampai dengan 20 Maret 1951. Kabinet ini di pimpin oleh Perdana Menteri Mohammad Natsir dan didukung oleh Partai Masyumi dan ada beberapa menteri yang non partai. Pada awalnya kabinet ini merupakan kabinet koalisi, akan tetapi PNI sebagai partai terbesar kedua tidak diberikan kedudukan yang sesuai (Marwati Djoened Poesponegoro dan Nugroho Notosusanto, 2008: 308).

Berikut ini adalah keanggotaan pada masa Kabinet Natsir (Suharto, 2010: 25).

Perdana Menteri: Mohammad Natsir (Masyumi), Wakil Perdana Menteri: Sri Sultan Hamengku Buwono IX (non partai), Menteri Dalam Negeri: Mr. Assaat (non partai), Menteri Luar Negeri: Mr. Mohammad Roem (Masyumi), Menteri Pertahanan: Dr. Abdul Halim (non partai), Menteri Kehakiman: Mr. Wongsonegoro (PIR), Menteri Keuangan: Mr. Syafruddin Prawiranegara (Masyumi), Menteri Perdagangan dan Perindustrian: Prof. Dr. Soemitro Djojohadikoesoemo 
(PSI), Menteri Pertanian: Mr. Tandiono Manu (PSI), Menteri Perhubungan: Ir. Djuanda (non partai), Menteri Pendidikan Pengajaran dan kebudayaan: Dr. Bahder Djohan (non partai), Menteri Pekerjaan Umum dan Tenaga Kerja: Ir. Herling Johannes Loah (PIR), Menteri Kesehatan: Johannes Leimena (Parkinda), Menteri Perburuhan: Raden Panji Suroso (Parina), Menteri Sosial: F.S Haryadi (Partai Katolik), Menteri Agama: KH Wahid Hasyim (Masyumi), Menteri Penerangan: M.A. Pellaupessy (Fraksi Demokrasi), Menteri Negara: Harsono Tjokroaminoto (PSII)

Program Kabinet Natsir adalah; (1) mengadakan Pemilihan untuk memilih Konstituante, (2) Memajukan pada bidang perekonomian, kesehatan, dan bidang kesejahteraan rakyat, (3) Menyempurnakan pemerintahan dan militer (4) menyelesaikan masalah Irian Barat dan memulihkan keamanan serta ketertiban.

Kegagalan-kegagalan program kerja Kabinet Natsir membuat kabinet ini goyah yang terjadi pada awal tahun 1951. Kegagalan tersebut dipicu dari permasalahan Irian Barat yang tak kunjung selesai dengan pihak Belanda yang tidak mau mengembalikannya. Kemudian krisis ini menjadi membesar setelah munculnya mosi tidak percaya dari Hadikusumo, menganggap masalah pembentukan DPRD menguntungkan Partai Masyumi saja. (Kol. R.H.A Hidayat,
H. Ikin A. Gani dan Abu Chanif, 1992: 259).

PNI yang menuntut pemilihan anggota perwakilan daerah supaya lebih demokratis. Mosi ini diterima oleh pihak parlemen yang mengakibatkan hubungan kabinet dengan parlemen menjadi lebih kaku, ditambah dengan beberapa partai pendukung kabinet justru menarik menteri-menterinya dari kabinet seperti Partai Indonesia Raya (PIR) (Marwati Djoened Poesponegoro dan Nugroho Notosusanto, 2008: 308-309). Maka belum genap sampai satu tahun Natsir mengembalikan mandatnya kepada Presiden Soekarno.

\section{Kabinet Sukiman}

Di kembalikannya mandat Perdana Menteri kepada Presiden, memaksa terbentuknya kabinet baru untuk menjalankan roda pemerintahan selanjutnya. Kabinet kedua ini merupakan koalisi antara Partai Masyumi dan PNI, di bawah pimpinan Dr. Sukiman Wirjosandjojo (Masyumi) dan Suwirjo (PNI).

Program kerja Kabinet Sukiman antara lain: (1) bidang sosial-ekonomi mengusahakan kemakmuran bagi rakyat secepatnya dan memperbaharui hukum agraria agar sesuai dengan kepentingan petani, mempercepat persiapanpersiapan pemilihan umum, (2) bidang keamanan menjalankan tindakantindakan yang tegas sebagai negara 
hukum untuk menjamin keamanan dan ketentraman, (3) bidang politik luar negeri menjalankan politik bebas aktif serta memasukkan Irian Barat ke dalam wilayah Republik Indonesia (Marwati Djoened Poesponegoro dan Nugroho Notosusanto, 2008: 308 ).

Namun, Kabinet Sukiman juga mengalami hal yang sama dengan Kabinet Natsir yang tidak bertahan lama, hanya dalam 10 bulan (mulai dari April 1952 sampai Juni 1953), kabinet ini mendapat pertentangan baik dari dalam partai sendiri maupun parlemen. Kabinet ini dianggap melanggar politik bebas aktif dan lebih condong kepada Amerika Serikat.

Pasa masa Kabinet Sukiman ini menandatangani persetujuan bantuan ekonomi dan persenjataan dari Amerika Serikat kepada Indonesia atas dasar Mutual Security Act (MSA) (Kol. R.H.A Hidayat, H. Ikin A. Gani dan Abu Chanif, 1992: 260). Selain itu penyebab jatuhnya Kabinet Sukiman disebabkan karena lambannya dalam penanganan pemberontakan yang terjadi di daerah seperti pemberontakan Kahar Muzakkar di Sulawesi.

\section{Kabinet Wilopo}

Presiden Soekarno menunjuk Sidik Djojosukarto dan Prawoto Mangkusaswitu, mereka berasal dari partai PNI dan Masyumi agar membentuk kabinet yang baru, tetapi mereka yang sebagai formatur gagal menjalankan tugasnya. Maka Presiden Soekarno menunjuk Mr Wilopo dari partai PNI sebagai formatur baru dan tanggal 30 Maret 1952 Mr Wilopo mengajukan susunan kabinetnya (Marwati Djoened Poesponegoro dan Nugroho Notosusanto, 1974: 215-216).

Mr Wilopo berhasil menyusun kabinetnya dan dia menjadi ketuanya. Kabinet ini terdiri dari Partai PNI dan Masyumi yang masing-masing mendapatkan jatah 4 orang, PSI 2 orang, PKRI, Parkindo, Parindra, Partai Buruh dan PSII masing-masing 1 orang dan non partai 3 orang (Marwati Djoened Poesponegoro dan Nugroho Notosusanto, 1974: 216).

Program kerja yang ditawarkan dalam kabinet ini adalah, menyelenggarakan pemilu untuk memilih anggota Dewan Konstituante, DPR dan DPRD, (2) meningkatkan kemakmuran rakyat, (3) membebaskan Irian Barat, (4) menjalankan politik luar negeri bebas aktif (A. Kardiyat Wiharyanto, 2011: 78). Kabinet Wilopo menjalankan politik luar negeri yang bebas dan aktif, namun kabinet ini juga bertugas menghapuskan persetujuan dengan Amerika Serikat yang terjadi masa Kabinet Sukiman, dengan cara berusaha memperoleh bantuan dengan syarat-syarat yang kurang mengikat (M. C. Ricklefs, 2009: 508).

Kabinet ini telah berusaha menjalankan program kerja dengan baik, 
akan tetapi sama dengan kabinet sebelumnya, kabinet ini di jatuhkan dengan mosi tidak percaya. Mosi tidak percaya yang diajukan kepada parlemen adalah karena Kabinet Wilopo dianggap gagal dalam menangani pergolakan di daerah. Pergerakan-pergerakan daerah seperti yang terjadi di Sumatera dan Sulawesi akibat mereka tidak puas dengan pemerintahan pusat. Faktor utama diakibatkan karena tidak seimbangnya alokasi keuangan yang diberikan oleh pusat ke daerah. Karena daerah itu merasa bahwa banyak sumbangan yang telah mereka berikan berupa ekspor ke pusat, lebih besar dari pada yang dikembalikan pusat ke daerah (Marwati Djoened Poesponegoro dan Nugroho Notosusanto, 1974: 312). Akibatnya tahun 1953 secara resmi Kabinet Wilopo mengembalikan mandatnya kepada Presiden Soekarno.

\section{Kabinet Ali Sastroamidjojo I}

Kabinet berikutnya terbentuk pada tanggal 1 Agustus 1953, dengan Perdana Menteri Mr. Ali Sastromidjojo (PNI) dan Wakil Perdana Menteri Mr. Wongsonegoro (Partai Indonesia Raya). Di dalam kabinet ini Masyumi tidak turut serta, akan tetapi Nadhatul Ulama (NU) duduk di dalamnya.

Program kerja kabinet ini sebagai berikut; (a) program dalam negeri yang mencakup soal keamanan, pemilihan umum, kemakmuran dan keuangan, serta dalam organisasi negara, perbaharuan, dan perundang-undangan, pengembalian Irian Barat, dan (c) politik luar negeri bebas aktif (Ginandjar Kartasasmita, A. Prabowo dan Bambang Kesewo, 1995: 363).

Pada masa Kabinet Ali I ini peristiwa besar Konferensi Asia Afrika atau (KAA) berhasil diselenggarakan di kota Bandung. Konferensi Asia Afrika digagas oleh Perdana Menteri Indonesia (Ali Sastroamidjojo), Perdana Menteri Srilanka (Sir John Kotelawala), Perdana Menteri Birma (U Nu), Perdana Menteri India (Jawaharlal Nehru), dan Perdana Menteri Pakistan (Mohammed Ali). KAA diselenggarakan pada bulan April 1955.

Konferensi ini kebanyakan diikuti oleh negara-negara ketiga yaitu negaranegara berkembang di wilayah AsiaAfrika yang baru saja memperoleh kemerdekaannya. Konferensi Asia Afrika (KAA) ini memiliki tujuan untuk menjalin kerjasama negara-negara asia-afrika di bidang ekonomi dan kebudayaan dan untuk melawan kolonialisme atau neokolonialisme Amerika Serikat, Uni Soviet, atau negara imperialis lainnya (Seno Joko Suyono dan Philipus Parera, 2015: 57).

Berhasilnya Indonesia sebagai negara yang ikut serta dalam penyelenggaraan Konferensi Asia Afrika di Indonesia berkonstribusi bagi negaranegara berkembang di kancah Internasional setelah mereka merdeka. 
Selain itu pada masa Kabinet Ali I ini juga pemilu sudah direncanakan akan diadakan.

Pada masa ini telah direncanakan pemilihan umum yang akan di selanggarakan pada pertengahan tahun 1954 (Zulkarnain, 2012: 114). Belum sempat pemilihan umum dilaksanakan Kabinet Ali telah jatuh karena NU menarik diri dari kabinet, karena perseteruan dengan PNI. Selain itu dikarenakan keadaan ekonomi yang semakin buruk dan korupsi yang mengakibatkan kepercayaan rakyat merosot pada Kabinet Ali I (Marwati Djoened Poesponegoro dan Nugroho Notosusanto, 1974: 219).

\section{Kabinet Burhanudin Harahap}

Kabinet Ali-Wongso digantikan oleh Kabinet Burharuddin Harahab pada 12 Agustus 1955. Burharuddin Harahab dari Masyumi berhasil menyusun suatu kabinet yang didasarkan pada dukungan Masyumi bersama PSI dan NU (12 Agustus 1955-3 Maret 1956). Dalam Kabinet Burharudin Harabap, memiliki beberapa program kerja yang hampir sama dengan kabinet sebelumnya, salah satu program kerja dalam kabinet ini yaitu mengembalikan kewibawaan moril pemerintah. Progam kerja yang sangat diprioritaskan dalam kabinet ini adalah untuk melaksanakan Pemilihan Umum.

Kabinet ini berlangsung antara 12 Agustus 1955-3 Maret 1956. Pada masa
Kabinet Burhanudin Harahap berhasil melaksanakan pemilu tanggal 29 September 1955. Pemilihan Umum sebagai sarana penting demokrasi sebetulnya sudah masuk agenda kerja kabinet parlementer pertama dibawah pimpinan Natsir, dan juga ada dalam program Kabinet Sukiman, tetapi belum sempat dilaksanakan oleh mereka keburu dijatuhkan kabinet. Baru pada era Kabinet Wilopo sebuah Rancangan Undang-undang Pemilu diajukan ke parlemen (DPRS, DPAS) dan disahkan menjadi UU (Atmadji Sumarkidjo, 2000: 71-72).

Pemilihan ini di gunakan untuk memilih 257 anggota DPR dan pada tanggal 15 Desember 1955 untuk memilih 514 anggota konstituante (Zulkarnain, 2012: 115) Hasil Pemilu 1955 memunculkan empat kekuatan partai besar, yaitu; (1) PNI, (2) Masyumi, (3) NU, dan (4) PKI. Hasil pemilihan umum baik di DPR maupun konstituante adalah sebagai berikut: a) Perolehan kursi di DPR, Masyumi 57 kursi, PNI 57 kursi, NU 45 kursi, PKI 39 kursi, peserta lain 81 kursi. b) Perolehan kursi di Konstituante, Masyumi 119 kursi, PNI 112 kursi, NU 91 kursi, PKI 81 kursi, peserta lain 118 kursi.

Namun, ternyata hasil pemilu tidak memuaskan pihak manapun, terutama dua partai besar yaitu Masyumi dan PNI. Keduanya menginginkan memperoleh dukungan yang mutlak (Zulkarnain, 2012: 115). Ketidakpuasan 
tersebut inilah menyebabkan banyak partai yang menarik menteri-menterinya untuk keluar dari kabinet tersebut. Akhirnya pada tahun 1956 Burhanudin Harahap mengembalikan mandatnya kepada Presiden Soekarno (M.C. Ricklefs, 2009: 522).

\section{Kabinet Ali Sastroamidjojo II}

Kabinet Ali II merupakan sebuah kabinet koalisi PNI-Masyumi-NU. Kabinet ini berlangsung sejak 20 Maret 1956-4 Maret 1957. Program kerja yang diusung oleh Kabinet Ali II adalah (a) pembatalan hasil perjanjian KMB, menyelesaikan pembatalan seluruh perjanjian yang dihasilkan Konferensi Meja Bundar secara Unilateral baik formal maupun materiil dan mengadakan tindakan-tindakan untuk menampung akibat yang dihasilkan (b) meneruskan perjuangan mewujudkan kekuasaan de facto Indonesia atas Irian Barat berdasarkan kekuatan rakyat dan kekuatan-kekuatan anti kolonialisme di dunia Internasional dan membentuk Provinsi Irian Barat, (d) menjalankan politik luar negeri yang bebas dan aktif berdasarkan kepentingan rakyat dan menuju ke perdamaian dunia, (e) meneruskan kerjasama dengan negaranegara Asia-Afrika dan melaksanakan keputusan-keputusan Konferensi AsiaAfrika di Bandung (Ginandjar Kartasasmita, A. Prabowo dan Bambang Kesewo, 1995: 30).
Sama dengan kabinet-kabinet sebelumnya, Kabinet Ali II ini juga berusia pendek. Hal ini disebabkan karena seringnya terjadi perbedaan pendapat koalisi orang-orang di dalam kabinet. Selain itu sikap oposisi dari Presiden Soekarno yang menghendaki pembentukan kabinet berkaki empat. Presiden Soekarno menginginkan kabinet berkaki empat dengan inti pendukung PNI, Masyumi, NU dan PKI (Zulkarnain, 2012: 116). Sedangkan kabinet bentukan Ali II ini tidak mengikut sertakan PKI sebagai partai koalisi.

Pada masa Perdana Menteri Ali II, Wakil Presiden Moh. Hatta mengundurkan diri dari jabatannya. Karena setelah terbentuk DPR dan Konstituante, Hatta berfikiran bahwa dirinya sudah harus melepaskan jabatannya. Selain itu, ada hal lain yang menyebabkan Moh Hatta mengundurkan diri dari jabatannya, yaitu perbedaan pandangan dengan Presiden Soekarno dalam arah politik, mereka selalu terjadi perbedaan pendapat dalam mengambil keputusan (Ginandjar Kartasasmita, A. Prabowo dan Bambang Kesewo, 1995: 19).

\section{Kabinet Djuanda}

Setelah Kabinet Ali Sastromidjojo II jatuh, Presiden Soekarno menunjuk Soewirjo menjadi formatur dalam membentuk kabinet baru. Dua kali Soewirjo berusaha, tetapi gagal 
membentuk kabinet. Dengan gagalnya Soewirjo, akhirnya Presiden Soekarno menunjuk dirinya sendiri sebagai formatur. Formatur Ir. Soekarno membentuk Kabinet Darurat EkstraParlementer dan menunjuk Ir. Djuanda sebagai Perdana Menteri. Kabinet Djuanda ini juga diberi nama Kabinet Karya dan di dalamnya duduk dua orang anggota Angkatan Bersenjata, dan satusatunya kabinet yang tidak berasal dari partai politik.

Kabinet Djuanda berlangsung antara April 1957-Juli 1959. Program kerja kabinet ini antara lain; (a) membentuk suatu Dewan Nasional, (b) normalilasi keadaan negara Republik Indonesia, (c) melanjutkan pembatalan perjanjian Konferensi Meja Bundar, (d) memperjuangkan Irian Barat (e) mempercepat pembangunan (Ginandjar Kartasasmita, A. Prabowo dan Bambang Kesewo, 1995: 42).

Meskipun telah beberapa kali mengganti kabinet saat itu, pergolakanpergolakan di daerah seakan tidak ada habisnya. Di masa Kabinet Djuanda ini masih terjadi peristiwa pemberontakan PRRI dan Permesta. Pemberontakan PRRI-Permesta bermula dari konflik internal Angkatan Darat. Kekecewaan atas minimnya kesejahteraan anggota di Sumater dan Sulawesi mendorong beberapa tokoh militer menentang kebijakan KSAD dan pemerintahan pusat. Hal ini kemudian meluas pada tuntutan otonomi daerah yang melibatkan para politisi (Daud Aris Tanudirjo, 2011: 305).

Dalam masa Kabinet Djuanda, pergolakan-pergolakan besar dari daerah yang tidak puas dengan kebijakan pemerintah pusat yang tidak memikirkan pembangunan daerahnya. Setiap daerah yang tidak puas dengan kebijakan pemerintah, melakukan perlawanan dengan membentuk organisasi militer yang bertujuan menentang pemerintah pusat. Seperti di Sumatera Barat terjadi perebutan kekuasaan setempat yang dilakukan oleh Dewan Banteng pada 20 Desember 1956. Mereka melepaskan diri dari Pemerintah Pusat. Peristiwa yang serupa timbul pula di Sumatera Utara (Medan) pada tanggal 22 Desember 1956 yang dilakukan oleh Dewan Gadjah. Menyusul pula Dewan Garuda di Sematera Selatan yang melakukan perebutan kekuasaan pada bulan Januari-Februari 1957. Pada tanggal 2 Maret 1957 di Makassar diumumkan Piagam Perjuangan Semesta (Piagam Permesta) yang meliputi daerah Sulawesi, Maluku, dan Nusa Tenggara (C.S.T. Kansil dan Julianto,1972: 66).

Hal ini membuktikan bahwa pemerintah belum bisa dalam merangkul semua golongan dan daerah-daerah di Indonesia untuk bersatu mempertahankan kemerdekaan yang telah dibangun ini. Kemudian kabinet Djuanda jatuh ketika Presiden merencanakan dekrit pada bulan Juli 
1959 (Zulkarnain, 2012: 117). Dekrit Presiden akhirnya dikeluarkan karena konstituante dianggap gagal dan belum mampu membentuk UUD baru sebagai pengganti UUDS terjadi pada tanggal 9 Juli 1959 yang mengakhiri demokrasi liberal di Indonesia.

\section{KESIMPULAN}

Demokrasi Liberal di Indoensia berlangsung 17 Agustus 1950 sampai 5 Juli 1959 yang disebut dengan sistem Parlementer. Perancang landasan dasar demokrasi liberal atau sistem parlementer di Indonesia oleh Panitia Gabungan RIS dan RI atau disebut dengan Panitia Persiapan Undang-Undang Dasar Negara Kesatuan. Landasan demokrasi liberal adalah UUDS 1950. Alat-alat kelengkapan negara dalam UUDS 1950 ketentuan Umum, pasal 44 disebutkan yaitu Presiden dan Wakil Presiden, menteri-menteri negara, Dewan Perwakilan Rakyat, Dewan Pengawas Keuangan dan Mahkamah Agung. Demokrasi Liberal berjalan 9 tahun antara 17 Agustus 1950-5 Juli 1959. dan telah 7 kali pergantian kabinet antara lain: Kabinet Natsir, Kabinet Sukiman, Kabinet Wilopo, Kabinet Ali Satromidjojo I, Kabinet Burharuddin Harahap, Kabinet Ali Satromidjojo II dan terakhir Kabinet Djuanda.

\section{DAFTAR PUSTAKA}

Djoened, Marwati Poesponegoro., Notosusanto, Nugroho. 1974.
Sejarah Nasional Indonesia VI. Jakarta: Balai Pustaka.

Djoened, Marwati Poesponegoro., Notosusanto, Nugroho. 2008. Sejarah Nasional Indonesia VI Zaman Jepang dan Zaman Republik Indonesia (1942-1998). Jakarta: Balai Pustaka.

Gazali, Zulfikar dkk.1980. Sejarah Politik Indonesia. Jakarta: Kementrian Kebudayaan Direktorat Sejarah dan Nilai Tradisional, Proyek Inventarisasi dan Dokumentasi Sejarah Nasional.

Gonggong, Anhar., Musa, Asy'ari (eds).2005. Sketsa Perjalanan Bangsa Berdemokrasi. Jakarta: Departemen Kominfo.

Joko, Seno Suyono., Parera, Philipus.2015. 60 Tahun Konferensi Asia-Afrika. Jakarta: Kepustakaan Populer Gramedia.

Kansil, C.S.T., Julianto. 1972. Sedjarah Perjuangan Pergerakan Kebangsaan Indonesia. Djakarta : Erlangga.

Kardiyat, A. Wiharyanto. 2011. Sejarah Indonesia: Dari Proklamasi sampai Pemilu 2009. Yogyakarta: Universitas Sanata Dharma.

Kartasasmita, Ginandja dkk.1995. 30 Tahun Indonesia Merdeka, Jilid I. Jakarta: Sekretariat Negara Republik Indonesia. Kartasasmita, Ginandjar dkk. 1995. 30 Tahun Indonesia Merdeka, Jilid II. 
Jakarta: Sekretariat Negara Republik Indonesia.

Kol. R.H. A Hidayat dkk. 1992. Indonesia Menyongsong Era Kebangkitan Nasional Kedua. Jakarta: Sandaan.

Notosusanto, Nugroho. 1984. Masalah

Penelitian Sejarah Kontemporer (Suatu Pengalaman). Jakarta: Yayasan Penerbit UI.

Ricklefs, M. C. 2009. Sejarah Indonesia Modern 1200-2008. Jakarta: Serambi Ilmu.

Soepomo.1950. Undang-Undang Dasar Sementara Repubik Indonesia (UUDS 1950). [tanpa kota terbit: tanpa penerbit]

Suharto.2010. Indonesia dalam Arus Sejarah, Jakarta: PT Ichtiar Baru van Hoeve.

Sumarkidjo, Atmadji. 2000. Mendung Di Atas Istana Merdeka. Jakarta: Pustaka Sinar Harapan
Zulkarnain. 2012. Jalan Meneguhkan Negara Sejarah Tata negara Indonesia.Yogyakarta: Punjangga Perss Zulkarnain.2012."Dinamika

Ketatanegaraan Indonesia”. Istoria. Volume II No. 1/2012. HIm. 1-15. 
Sistem Ketatanegaraan Indonesia Pada Masa Demokrasi Liberal..., Johan Setiawan,dkk, 365-378 